\title{
The Impact of Using Electronic Games on Teaching English Vocabulary for Kindergarten Students
}

\author{
Amal Shehadeh AlNatour, Dima Hijazi \\ Yarmouk University, Irbid, Jordan
}

\begin{abstract}
The aim of this study is to investigate the impact of using electronic games on teaching English vocabulary to kindergarten students to find out if these selected games could facilitate the competences of English language learners. To accomplish the goal of the study, a pre- and post- test was conducted in order to measure the level of the students in English. The sample of the study consisted of 100 kindergarten students in private kindergartens in Irbid during the first semester 2016-2017 and was given out into four parties, which were chosen purposefully: two experimental and two control groups. The results of the study indicated that there were statistically significant differences in the post-test between the control and the experimental groups in favor of the experimental group. Furthermore, there were no statistically significant differences in the achievement of the students due to gender or to the interaction between group and gender.
\end{abstract}

Keywords: electronic games, impact, teaching English vocabulary, English as a foreign language (EFL), kindergarten students

\section{Introduction}

English language plays a crucial role these days. It is one of the main elements in any educational system. Frankly speaking, educational institutions recognized the importance of English since it is an international channel of communication (Wallace, 1992, as cited in Hijazi, 2012). As a result, English is taught at schools and universities in all over the world, and in some countries, teaching it as a foreign or a second language.

As a foreign language, English learners do not only need to be good at the four skills (writing, speaking, reading, and listening), but also they should be good at vocabulary. In fact, many researchers have defined the word vocabulary. For example, Hubbard (1983) said that it is a strong and influential bearer of meaning. Diamond and Gutlohn (2006) mentioned that vocabulary is the lore of words and their significations. The previous definitions indicated that without building a powerful vocabulary foundation, comprehension and appropriate language use will not be obtained and acquired.

In fact, vocabulary is the heart of any language since without having enough storage of vocabulary and students will not be able to understand English well to communicate with their peers or to express their own ideas in front of others (Cardenas, 2001). Wilkins (1972, pp. 111-112) asserted that "Without vocabulary nothing can be conveyed." Besides, vocabulary essentially links the four skills of language altogether (Huyen \& Nga, 2003) since students' knowledge of it affects positively their abilities to read, write, listen, and speak. 
Vocabulary learning is the cornerstone of students' level of comprehension (Nation, 2001; McKeown, 2002). Therefore, learning vocabulary in a suitable way leads to students' learning success in general.

Since vocabulary is a key factor in the process of language teaching and learning, teachers need to use effective ways and appropriate strategies to help students to develop their vocabulary knowledge in order to enhance their language comprehension and production abilities. Unfortunately and surprisingly, some teachers in foreign contexts in general still use traditional ways to teach vocabulary. Some of them use drilling and memorization as immediate ways of teaching and practicing vocabulary to get the students produce the correct pronunciation of words. Such traditional ways focus on teaching vocabulary out of context, as isolated words.

As a result, students face many difficulties in learning vocabulary. Decarrico (2001) indicated that memorization without understanding is not an ideal way to learn words. Besides, traditional ways used for teaching vocabulary do not enable students to be involved in the process of learning since teachers are the center of the class and maybe are the main source of vocabulary information in addition to dictionaries. As a result, new ways for teaching vocabulary and for enriching students' vocabulary knowledge are of critical importance nowadays. Teachers should be facilitators and guides since students can learn more when they are appropriately involved in the process of learning (Ferriera, 2007).

Frankly speaking, modern ways prove to be more suitable and motivating for teaching vocabulary than the traditional ones (Costica, 2015). We live in a world, in which change is a norm and students need to learn vocabulary in an appropriate way to cope with the world of technology so that they are not left behind as the world moves on. As a result, teachers need to use modern strategies to enhance students' vocabulary learning, such as CALL (computer assisted language learning), games, drama, and role-play (Rohani \& Pourgharib, 2013). Using electronic games for teaching vocabulary is the main focus of this paper. Wright, Betteridge, and Buckby (2005, as cited in Rohani \& Pourgharib, 2013, p. 3541) mentioned that "With the use of games, the teacher can create various contexts, in which students have to use the language to communicate, exchange information, and express their own opinions."

Using games in order to teach vocabulary is one of the novel methods that are used nowadays, since it is considered as a new trend to strengthen and improve students' abilities in English. Longman Dictionary of Language Teaching and Applied Linguistics (Richards, Platt, \& Platt, 1995, p. 89) defined games as "an organized activity that usually has the following properties: a particular task or objective, a set of rules, a competition between players, and a communication between players by spoken or written language." However, many researchers agreed upon such definition and commented positively on it, such as Deng (2006) and many others.

In fact, many researchers, such as Pound (2005), Wright et al. (2005), and Zheng (2008), asserted that using games in learning has many advantages. It enhances students' motivation and self-confidence if learning takes place in a relaxing environment. Students may acquire new words naturally in a normal way since games bring amusement for them. Besides, it creates a real life situation for using language (Lee, 1995). Because they are amusing and interesting, games are considered as highly motivating and they may develop learners' social skills and build team spirit among students and their peers (Ersoz, 2005). Furthermore, games may develop spatial, bodily kinesthetic, and interpersonal intelligences as indicated by Gardner (1999). According to Dourda et al. (2013), game-based learning makes language learning exciting and amusing and provide learning atmosphere that contextualize knowledge. 
In addition, games may promote the transfer of learning. In fact, they demand student engagement and dynamic participation using the curriculum material in full context, and therefore, they promote transfer (Cruickshank \& Telfer, 2001). When the student has the chance to apply the material, such as in a game, it can delete the gap between learning ideas given in a classroom and using that data to figure out a dilemma outside the school. As a result, to achieve the desired benefits from learning games, it is crucial that they are accepted as a learning way, rather than to waste time.

On the other hand, some researchers, such as Zeng (2005) and Chuang (2007) indicated that using games in learning English vocabulary is not efficient enough or not productive enough as required. Despite the fact that they enhance students' vocabulary acquisition, a minority of students, especially children, may feel nervous and even depressed because they may feel afraid of being blamed by their peers if they lose games (peer pressure).

However, the success of using games for teaching vocabulary should be held upon teachers' shoulders. They need to choose the appropriate games that suit students' proficiency levels, interests, styles, and characteristics. Also, they need to know how to design their teaching plans since different games serve different purposes. Furthermore, they need to know how to implement different games in real classes (Ampaipan, 1999). Besides, teachers need to use more cooperative games to reduce the anxiety of students and to create fun in the classrooms.

Generally speaking, students face many difficulties while learning vocabulary. Some teachers still use traditional ways to teach vocabulary and still reckon that games are a time loosing activities and are just for fun. Besides, some of them are not trained enough on how to implement games during English lessons. Therefore, the problem of learning and teaching vocabulary deserves to be studied. In this paper, the researchers discuss the effects of using electronic games on teaching English vocabulary for Jordanian kindergarten students as an example of learners who learn English as a foreign language (EFL).

\section{Statement of the Problem}

According to the researchers' knowledge, many students encounter some difficulties learning EFL and difficulties learning vocabulary in particular. In fact, vocabulary retention, particularly in an EFL context, is effortful prospect while learning a foreign language. The success of English language learners depends on learning vocabulary in an appropriate way. The number of new vocabulary terms should suit students' levels and their mental capacities and should be gradually taught throughout different classes. The researchers noticed that some Jordanian teachers give their students a large number of words during one class, while Gersten and Baker (2000) indicated that students should not learn more than 20 new vocabularies in one class, since it is not an effectual method to develop their vocabulary. Besides, the researchers noticed that some Jordanian teachers use traditional ways in teaching vocabulary neglecting using modern methodologies, such as games since we are living in very high technological settings.

\section{Significance of the Study}

It is desired that the findings of this study can be significant for teachers, students, and textbooks designers and developers as follows.

Firstly, the outcomes of this project may suggest modifications for the syllabi of the textbooks taught at the school level or at the university one. Thus, this study may contribute to the educational knowledge base of 
those who are engaged in the process of developing and assessing the English textbooks to integrate different games for teaching the four skills of language and even for teaching grammar.

In addition, this study sheds light on the effectiveness of using games to teach vocabulary. Therefore, the results may present solutions to overcome the difficulties of learning English vocabulary using other modern strategies besides games to improve teaching vocabulary in particular and teaching English in general.

Besides, the results may help both teachers and students to have better attitudes towards using games in the classroom especially for those who have negative ones. Furthermore, the results of this study may encourage the Jordanian Ministry of Education to conduct training programs to train teachers on how to select the appropriate strategy to teach vocabulary and on how to implement such strategy in real classes.

Finally, the results can be used as a reference for other researchers to conduct further research in other contexts.

\section{Purpose of the Study}

The main aim of this study is to look into the effect of applying online word games on kindergarten students' achievement in English vocabulary in private kindergartens in Irbid, Jordan.

\section{Questions of the Study}

1. Are there any statistically significant differences $(\alpha \leq 0.05)$ in the achievement of the kindergarten students in English language vocabulary due to the teaching strategy they are exposed to (using electronic or old traditional ways)?

2. Are there any statistically significant differences $(\alpha \leq 0.05)$ in the achievement of the kindergarten students in English language vocabulary due to gender?

\section{Definition of Operational Terms}

There are two definitions of operational terms in the paper as the following:

1. English Language Vocabulary: In this study, they are a group of words that exist in the kindergarten students' book;

2. Kindergarten: It is a pre-school educational institution for children.

\section{Limitations of the Study}

This study is specified to kindergarten students at all private kindergartens in Irbid, Jordan. Moreover, it is limited to electronic games among other games. It is limited to teaching vocabulary which is an essential element that links the four skills of language altogether.

\section{Review of Related Literature}

\section{Theoretical Framework}

When acquiring English language, the learner has to deal with unfamiliar vocabulary. In the classroom, students should engage in various task-based activities, such as describing, guessing, and conversation exercises, to help them learn and absorb new vocabularies. Another activity is vocabulary games, which specifically concentrate on assisting students to develop and use vocabulary in various situations, making the lessons pleasurable and exciting. So, there is a necessity to investigate if students can learn words effectively through these types of activities, and how they comprehend them. 
Generally, vocabulary is not taught as a segregated subject but is taught within reading, listening, speaking, and writing lessons. In the lesson, students employ their own vocabulary and are presented to novel words that the teacher and peers in the classroom provide, and these are applied to classroom activities. A lot of learners of English consider vocabulary as a tilt of new words with meanings in their native language and do not have any real practice of these words. Students of a language may have the same experience of looking for definitions of new words in bilingual dictionaries. Also, learners may just write a tilt of these novel vocabularies without knowing their real use in context. After a while, using these methods to learn vocabulary, learners find that they are unsatisfied and think their bad memorization is the cause (Gnoinska, 1998). Various research papers have depicted that this method of studying is not very effectual. Therefore, vocabulary games (as an example of modern ways used to teach vocabulary) are suggested to solve some of the common problems related to vocabulary learning.

\section{Empirical Studies on the Impact of Games on Students' Learning}

There are few studies that examined the effect of games on English students' learning abilities especially in vocabulary. Segers and Verhoeven (2003) conducted a study to reveal the effect of computer training program on students' vocabulary learning. The sample of the study consisted of 67 native and immigrant children in Netherlands who were in the first and the second years of kindergarten. The experimental group played computer vocabulary games for 15 weeks (two times every week) whereas the control group (97 kindergarten students) were taught using the regular curriculum. The results revealed that computer vocabulary games had a positive effect on students' vocabulary learning in general.

Aghlara and Tamjid (2011) investigated the effect of using a digital computer game on enhancing English vocabulary of Iranian children. The experimental group was taught using "SHAIEx" digital game whereas the control group was taught through traditional methods. The results showed that children in the experimental group performed significantly better than those in the control group. The researchers recommended using digital games in teaching English vocabulary to children.

Wang, Shang, and Briody (2011) examined the total effects of using games on enhancing young children's English proficiency in terms of motivation, vocabulary acquisition, and anxiety resulting from peer pressure. The sample of the study consisted of 50 Grade 6 EFL students from one elementary school. The results showed that students' motivation and vocabulary acquisition significantly improved, and that their level of anxiety resulting from peer pressure was decreased when learning via games.

Yunus et al. (2012) studied the effect of video games on students' writing abilities and their attitudes toward using such games in teaching writing. The main focus of the study was on two specific skills which are vocabulary acquisition and narrative skills. The instruments of the study were questionnaire surveys followed by semi-structured interviews with the study sample. One of the main results was that most of the students found that video games enhanced their vocabulary and that those words learnt were used in their English writing activities. The previous study proved the relationship between vocabulary and other language skills, such as writing and how games can affect positively students' vocabulary and consequently the other language skill.

Aslanabadi and Rasouli (2013) conducted a study to examine the effect of using games on the vocabulary knowledge of Iranian EFL students in kindergartens. The sample of the study consisted of 60 students who were divided into two groups. The experimental group consisted of 30 students (15 boys and 15 girls) were 
taught by using an online language teaching game (taken from: http//anglomaniacy.pl). On the other hand, the control group consisted of 30 students ( 15 boys and 15 girls) were taught by using the regular curriculum. The findings of the study revealed that that there are statistically significant differences between the two groups in favor of the experimental group. The researchers strongly recommended using games for teaching vocabulary.

Rohani and Pourgharib (2013) conducted a study to find out the effect of games on students' vocabulary gains. The sample of the study consisted of 30 female students from first-grade junior high school who were divided into control and experimental groups. The control group was vulnerable to textbook teaching whereas the experimental group was taught by games. Although both groups made dramatic progress after training program, there was no significant difference between the two groups.

Vahdat and Behbahani (2013) conducted a study to find out the effect of video games on Iranian students' EFL vocabulary learning. The participants of the study were 40 intermediate EFL learners who were divided into two groups. The experimental group consisted of 20 students (10 male and 10 female) who studied vocabulary in a traditional way. While the control group which consisted of 20 students (10 male and 10 female) studied vocabulary (the same words) by a video game called "Runaway: A Road Adventure." The results showed that learning vocabulary by video games is useful and males are more bended toward learning via video-games than females.

Ashraf, Motlagh, and Salami (2014) asserted the effectiveness of using online games for teaching vocabulary to Iranian EFL students. The sample of the study was 24 low-intermediate EFL learners, who were divided into experimental and control groups. The experimental group was taught some new words via online computer games. The period of the study was 15 weeks. The results showed that the performance of the experimental group was better than the control group who was taught via traditional methods. As a result, online games are more effective in learning English vocabulary for students.

Alshaiji (2015) investigated the effect of video games and their role in enhancing English vocabulary retention of Saudi kids. The study aimed to answer if there was a statistically significant difference $(\alpha=0.05)$ between the Saudi children's scores on the English vocabulary test due to using video games activities in kindergarten or not. The sample consisted of 60 (30 of them comprised the experimental group whereas the other 30 comprised the control group) female Saudi kindergarten students in Riyadh. Video games used for teaching vocabulary to the experimental group were taken from the official site of the British Council for teaching vocabulary, whereas traditional methods were used for teaching vocabulary to the control group. Collected data was analyzed using ANCOVA (analysis of covariance) analysis. The results showed that kids in the experimental group performed significantly better than those in the control group. The researcher recommended that kindergartens' teachers should adopt video games activities in their classroom practices to improve children's English vocabulary retention.

\section{Methodology}

In the current section the researchers talked about the procedures that they used to carry out the study. They specified the study sample, population, variables, instrument, procedures, and the statistical analyses they have used.

\section{Population and Sample of the Study}

The population of the study was all kindergarten students in Irbid who were enrolled in the second 
semester 2016-2017 and they form 1,890 females and males. The sample was chosen purposefully and it consisted of 100 students who were divided into control group (55) and experimental one (45). The distribution of the sample is shown in Table 1.

Table 1

Distribution of the Subjects of the Study According to the Variables of Group.

\begin{tabular}{lll}
\hline Group & Gender & $N$ \\
\hline \multirow{3}{*}{ Experimental } & Male & 23 \\
& Female & 22 \\
& Total & 45 \\
\hline \multirow{2}{*}{ Control } & Male & 27 \\
& Female & 28 \\
& Total & 55 \\
\multirow{2}{*}{ Total } & Male & 50 \\
& Female & 50 \\
\hline
\end{tabular}

\section{Design of the Study}

The participants of the study were divided into two groups: the control group and the experimental group. For eight weeks, the participants of the experimental group were taught vocabulary using online games, whereas, for the same period, the participants of the control group were taught using a traditional way. A pre-test was given to both groups before the application of the treatment in order to assure they are equivalent and a post-test administered after applying the treatment to measure the using of online games on teaching English vocabulary on the experimental group, and which technique has bigger influence on the students' performance than the other.

\section{Instrument of the Study}

The researchers used two techniques for teaching English vocabulary: using online games technique and a traditional one. After that, the researchers designed a test based on the instructional material of the kindergarten English book and collected the data. Reliability and validity were checked. Both groups (the experimental and the control) were taught by their teachers. The students in both groups took a pre-test at the beginning of the experiment and a post-test at the end of the experiment. There were eight weeks between the pre- and post- test, and an enough period to decrease the outcome of the pre-test on the results and conclusions of the experiment.

\section{Reliability of the Instrument}

The researchers followed test/retest technique in order to ensure the test reliability. The tests were applied to a pilot sample of 20 students who were excluded from the study and with a two-week period between the test and the retest. The correlation coefficient was used to measure the reliability of the test which was 0.89 .

\section{Validity of the Instrument}

The validity of the instrument was ensured by asking a jury of four supervisors of English language working at the Directorate of Education in Irbid and two kindergarten teachers to take their comments into consideration.

\section{Instructional Material}

The kindergarten English textbook was the instructional material, which included more than 20 new vocabularies, but the researchers decided to cover minimum 10 words during the application period. 


\section{Procedures of the Study}

The two experimental and two control groups received eight weeks of instructions concerning English vocabulary. The experimental groups were instructed certain vocabularies using online games, whereas the control groups were taught using the traditional teaching where words to be memorized and pictures given by the teacher from text books and other materials. The main focus of the traditional way was drilling and memorizing.

\section{Statistical Analyses}

Descriptive methods (means and standard deviations) were used for pre and post-tests to both the experimental and control groups concerning English vocabularies in order to answer the questions of the study. Moreover, a two-way ANOVA (analysis of variance) was used to answer the questions of the study and a $t$-test was used to show equivalence.

\section{Results of the Study}

The main goal of this paper is to study the effect of using online games on kindergarten students' achievement in English vocabulary in private kindergartens in Irbid. The equivalent pre- and post- test two group designs were conducted by the researchers. Therefore, data were analyzed by computing the means, standard deviations, and two-way ANOVA. The findings of the study were presented according to the questions of the research.

To decide if there was a statistically significant difference between the female and the male groups, a $t$-test for independent samples was used as shown in Table 2.

Table 2

Means and Standard Deviations of the Achievement of Male and Female Groups on the Pre-Test

\begin{tabular}{lllll}
\hline GROUP & Gender & Mean & Std. deviation & $N$ \\
\hline \multirow{3}{*}{ Experimental } & Male & 68.80 & 12.307 & 23 \\
& Female & 69.89 & 10.590 & 22 \\
& Total & 69.36 & 11.401 & 45 \\
\hline \multirow{3}{*}{ Control } & Male & 67.48 & 10.317 & 27 \\
& Female & 69.60 & 10.554 & 28 \\
& Total & 68.57 & 10.434 & 55 \\
\multirow{2}{*}{ Total } & Male & 68.15 & 11.332 & 50 \\
& Female & 69.75 & 10.515 & 50 \\
& Total & 68.98 & 10.916 & 100 \\
\hline
\end{tabular}

Table 2 shows that the difference between females and males in the four groups was not statistically significant at $\alpha=0.05$. Thus, the two groups (male and female) in both experimental and control groups were assumed similar and so the sample was divided into just two groups (an experimental and a control group).

To ensure if the two control and experimental groups were equivalent in their English vocabulary, a pre-test was held and the results are presented in Table 3. 
Table 3

T-Test Results of the Experimental and the Control Groups on the Pre-Test.

\begin{tabular}{llllll}
\hline Source & Type III sum of squares & $d f$ & Mean square & $F$ & Sig. \\
\hline Group & 28.893 & 1 & 28.893 & 0.240 & 0.625 \\
gender & 115.300 & 1 & 115.300 & 0.958 & 0.329 \\
*Group $\times$ gender & 11.684 & 1 & 11.684 & 0.097 & 0.756 \\
Error & 20936.903 & 174 & 120.327 & & \\
Corrected total & 21089.910 & 177 & & & \\
\hline
\end{tabular}

\section{*Group×gender: Interaction between group and gender}

According to the pre-test, Table 3 displays that there were no statistically significant differences at $\alpha=$ 0.05 between the control and experimental group's achievements so the two groups were assumed equivalent.

When the experiment completed, the researchers conducted a $t$-test for the independent samples to check if there was any statistically significant difference of the achievements between the males and the females on the post-test, which may be attributed to gender. Table 4 shows the results.

Table 4

Mean and Standard Deviations of the Achievement of Male and Female Groups on the Post-Test.

\begin{tabular}{lllll}
\hline GROUP & Gender & Mean & Std. Deviation & $N$ \\
\hline \multirow{3}{*}{ Experimental } & Male & 81.82 & 8.678 & 23 \\
& Female & 82.34 & 8.532 & 22 \\
& Total & 82.09 & 8.559 & 45 \\
\hline \multirow{3}{*}{ Control } & Male & 76.64 & 9.675 & 27 \\
& Female & 77.42 & 10.922 & 28 \\
& Total & 77.05 & 10.286 & 55 \\
\hline \multirow{3}{*}{ Total } & Male & 79.29 & 9.488 & 50 \\
& Female & 79.93 & 10.029 & 50 \\
& Total & 79.62 & 9.749 & 100 \\
\hline
\end{tabular}

Table 4 shows that the post-test of the experimental group and the control group presented a statistically significant difference at $\alpha=0.05$ between the achievement of the two groups in favor of the experimental group in which its mean was 82.09. This indicated that using online games for teaching English vocabulary for kindergarten students may have had a positive effect on children's performance in English language.

The results showed that using online games for teaching English vocabulary had the similar results on male and female students, in other words, there were no statistically significant differences between male and female achievements due to gender.

In order to analyze the post-test achievement scores of the two groups, the researchers also conducted a two-way analysis of variance. Table 5 shows the results.

Table 5

Summary of the Two-Way ANOVA of the Achievement of the Control and the Experimental Groups

\begin{tabular}{llllll}
\hline Source & Type III Sum of squares & $d f$ & Mean square & $F$ & Sig. \\
\hline Group & 1131.545 & 1 & 1131.545 & 12.562 & 0.001 \\
gender & 18.817 & 1 & 18.817 & 0.209 & 0.648 \\
*Group $\times$ gender & 0.734 & 1 & 0.734 & 0.008 & 0.928 \\
Error & 15673.719 & 174 & 90.079 & & \\
Corrected total & 16823.781 & 177 & & & \\
\hline
\end{tabular}




\section{*Group $\times$ gender: Interaction between group and gender}

Table 5 shows that there was a statistically significant difference between the experimental group and the control group on the post-test in favor of the experimental group. However, Table 5 also shows that there was no significant difference attributed to the interaction between the treatment and gender.

To sum up, the researchers believe that the differences in the achievements of the kindergarten children were referred to their using of online games for teaching English vocabulary. The experimental group subjects tried to develop English vocabulary they already have in a period of eight weeks, to the contrary of the control group learners whose improvements were not statistically significant. Moreover, the researchers indicated that the improvement achieved by the experimental group may have been attributed to the way the teachers provide pedagogy and instructions using online games. In other words, students were more involved in learning when they were given the opportunity to use online games to learn new vocabulary and have fun at the same time.

\section{Discussion of the Findings of the Study}

In Jordan, for a few years, learning vocabulary has been considered a tedious task and the traditional style of learning vocabulary by bare dictation and memorization has proved to be incompetent. Also, games are considered as activities to fill time in many English classrooms. It is understood that games are for enjoyment and have little effect on teaching and learning. Nevertheless, this study proves that games promote learning vocabulary, if students are given the opportunity to learn, practice, and to review the English language in an acceptable environment. From the research, the researchers concluded that students want novel methods of teaching vocabulary, and are themselves in search of novel methods.

Given these circumstances, games are recognized as having benefits and potency when learning vocabulary in various ways. Firstly, games are a means for students to relax and enjoy themselves, thus assisting them to learn and keep new words more easily. Secondly, games are usually competitive in a friendly way since they maintain learners excited and this is what motivates learners of English to be committed and interactively take part in learning activities. Thirdly, games that teach vocabulary, bring actual world contexts into the classroom, and enhance the students' use of English, in a responsive and expressive way.

Thus, the use of games to teach and learn vocabulary must not be overlooked. In fact, it is necessary to choose appropriate games in order to achieve the main objective of vocabulary games. The number of students, proficiency level, cultural context, timing, learning topic, and the classroom settings are rationales to be taken into considered when carrying out a game. The results of the this study are in line with different studies for example Aslanabadi and Rasouli (2013) pointed out that online language teaching game affect the kindergarten children's vocabulary learning and memorizing of the second language vocabularies. Moreover, Zheng (2008), Pound (2005), Wright et al. (2005), Lee (1995) and Ersoz (2005) claimed that using games in learning has many advantages that it is considered as a new trend to strengthen and improve students' abilities in English and also it may build team spirit among students and their peers and develop students' social skills. Gardner (1999) also indicated that it may develop spatial, bodily kinesthetic, and interpersonal intelligences. On the other hand, some researchers are against such results, such as Chuang (2007) and Zeng (2005) who indicated that it is not efficient enough or not productive enough as required to use games in vocabulary English learning that some students, especially children, may feel nervous and even depressed because they may feel afraid of being blamed by their peers when losing games or because of their accomplishment (peer pressure). 
The results of the statistical analyses of this research showed no significant differences between male and female language learners and both could profit from the utilization of electronical games inside the classroom to learn vocabularies regardless of their gender and this is in line with Mehregan (2014). On the other hand, the results of this study are not in line with Vahdat and Behbahani (2013) who stated that males are more inclined toward electronic games learning (video-game) than females.

\section{Conclusion}

English should be introduced to children in early stages to give them the chance to broaden their perspectives, rouse their early excitement, and wonder concerning languages. This eager desire to learn can be widened with dynamic teaching processes based on learning languages via discovering and playing. Learning the language for interaction and communication should be focused on also (Lefever, 2007). Considering these aims, inserting language learning in the early years can result in the child's accumulated self-confidence, enjoying learning, and active involvement in the overall society.

Also, the use of online games can aid children to learn vocabulary. Using games may indorse the learning of open vocabulary when the same vocabulary is learnt without applying games (Al-Mamary, 1998). The activities should be contrived according to the potentialities of young learners. According to Slattery (2005), the activities for very young learners teach vocabulary through play and interaction, but the activities for young learners include more participatory learning. A great number of learners consider games relaxing and motivating. Games should play a crucial role of classroom lessons being extremely enjoyable for both students and teachers. In this study, games are approved to be beneficial and effective in teaching vocabulary to very young learners. Therefore, this type of teaching method will allow students to be actively involved in a pleasurable manner.

\section{Recommendations}

The researchers of this study recommend the followings (If this study is to be repeated to arouse further significance, some changes should be made):

1. The experiment should be conducted over a longer period that enables students to get rid of the traditional ways of learning English vocabulary and become more acquainted with the using of online games;

2. The study should be performed on other samples of students to examine if there is a significant effect of using online games for teaching vocabularies.

\section{References}

Aghlara, L., \& Tamjid, N. H. (2011). The effect of digital games on Iranian children vocabulary retention in foreign language acquisition. Elsevier Procedia: Social and Behavioral Sciences, 29, 552-560.

Al-Mamary, N. N. (1998). Using songs to promote vocabulary learning in Grade 1. Retrieved May, 16, 2017, from http://wenku.baidu.com/view/bb719d15be23482fb4da4cfd.html?re

Alshaiji, O. A. (2015). Video games promote Saudi children English vocabulary retention. Education, 136(2), 123-132.

Ampaipan, R. (1999). 100 language games. Bangkok: Thaiwa Hanapanitch Press.

Ashraf, H., Motlagh, F. G., \& Salami, M. (2014). The impact of online games on learning English vocabulary by Iranian (low-intermediate) EFL learners. Procedia: Social and Behavioral Sciences, 98, 286-291.

Aslanabadi, H., \& Rasouli, G. (2013). The effect of games on improvement of Iranian EFL vocabulary knowledge in kindergartens. International Review of Social Sciences and Humanities, 6(1), 186-195.

Author 2. (2012). 
Cardenas, M. E. (2001). Issues on active speaking vocabulary assessment. Retrieved on December, 11, 2016, from http://www. teachingenglish.org.uk/think/vocabulary/working_with_vocabulary.shtml

Chuang, H. Y. (2007). The study of foreign language anxiety, English learning motivation and strategies in the elementary school (Unpublished Master's thesis, National Chiayi University, Chiayi, Taiwan).

Costica, L.(2015). Strategies for teaching and learning of the vocabulary English language in Romanian schools. International Journal of Innovation and Research in Educational Sciences, 2(5), 2345-5219.

Cruickshank, D. R., \& Telfer, R. (2001). Classroom games and simulations. Theory into Practice, 19(1), 75-80.

DeCarrico, J. (2001). Vocabulary learning and teaching. In M. Celcia-Murcia (Ed.), Teaching English as a second or foreign language (3rd ed., pp. 285-299). Boston: Heinle \& Heinle.

Deng, Q. H. (2006 ). A study of using games in primary school English teaching (Unpublished Master's thesis, Northwest Normal University, Shensi Province, China).

Diamond, L., \& Gultohn, L. (2006). Vocabulary handbook. Berkley, CA: Consortium of Reading Excellence. Retrieved on December 9, 2106, from http://eltj.oxfordjournals.org/cgi/content/abstract/50/1/52

Dourda, K., Bratitsis, T., Griva, E., \& Papadopoulou, P. (2013). Combining game based learning with content and language integrated learning approaches: A case study utilizing QR codes and googleearth in a geography-based game. The Electronic Journal of E-Learning, 12(3), 243-258.

Eroz, A. (2005). Six games for EFL 1 ESL Classroom. The Internet TESL Journal, 6(6). Retrieved on June 14, 2015, from http:// lliteslj.org llessonslEroz-Games.html

Ferreira, F. H. L. (2007). How to teach vocabulary effectively an analysis of the course book eyes and spies .Retrieved on June 20, 2016, from http://www.portaldoconhecimento.gov.cv/bitstream/10961/2431/1/lastversion.pdf

Gardner, H. (1999). Intelligence reformed: Multiple intelligences for the 21st century. Newyork: Basic Books.

Gersten, R., \& Baker, S. (2000). What we know about effective instructional practices for English language learners. Exceptional Children, 66(4), 454-470.

Gnoinska, A. (1998). Teaching vocabulary in color. English teaching forum, 36(3), p. 3.

Hijazi, D (2012). Difficulties Jordanian Non-English Major University Students Face while Learning English as a Foreign Language: A student Perspective. College of Education Journal, 26, 29-54. University of Aswan, Egypt.

Hubbard, P. (1983). A training course for TEFL. Oxford: OUP (Oxford University Press).

Huyen, N. T. T., \& Nga, K. T. T. (2003). Learning vocabulary through games: The effectiveness of learning vocabulary through games. Asian EFL Journal, 5(4), 90-105.

Lee, S. K. (1995). Creative Games for the Language Class. Form, 33(1). Retrieved on April 5, 2016, from http://lleca.state. govlforumlvolslvol33lno1l p35htm

Lefever, S. (2007). English for very young learners. Retrieved on March 20, 2016, from http://malfridur.ismennt.is/haust2006/ $\mathrm{pdf} / \mathrm{malfr}$ 27-31.pdf

Mehregan, M. (2014). Game-based tasks for foreign language instruction: Perspectives on young learners' vocabulary acquisition. The IAFOR Journal of Language Learning, 1(1), p. 1.

Nation, P. (2001). Learning vocabulary in another language. Cambridge: Cambridge University Press.

Pound , L. (2005). How children learn. London: Step Forward Publishing, Ltd.

Richards. J. C., Platt. J. T., \& Platt, H. K. (1995). Longman dictionary of language teaching and applied linguistics. Beijing: Foreign Language Teaching and Research Press.

Rohani, M., \& Pourgharib, B. (2013). The effects of games on learning vocabulary. International Research Journal of Applied and Basic Sciences, 4(11), 3540-3543.

Slattery, S. (2005). Technological skill as technological literacy: An argument for the value of writers' skill with information technology. Technical Communication, 52(3), 353-360.

Segers, E., \& Verhoeven, L. (2003). Effects of vocabulary training by computer in kindergarten. Journal of Computer Assisted Learning, 19(4), 557-566.

Vahdat, S.. \& Behbahani, A. (2013). The effect of video games on Iranian EFL learners' vocabulary learning. The Reading Matrix, 13(1), 61-71.

Wang, Y. J., Shang, H. F., \& Briody, P. (2011). Investigating the impact of using games in teaching children English. International Journal of Learning and Development, 1(1), 127-141. Retrieved from http://dx.doi.org/10.5296/ijld.v1i1.1118 doi:10.5296/ijld.v1i1.118

Wilkins, D. A. (1972). Linguistics in language teaching. London: Edward Arnold Ltd. 
Wright, A., Betteridge, D., \& Buckby, M. (2005). Games for language learning (3rd ed.). New York, NY: Cambridge University Press.

Yunus, M. M., Li, L. K. S., Said, N. E. M., Najah, K., Karim, A., RabItatul, A. J., \& Shamsul, M. A. S. (2012). Educational gaming: The influence of video games on ESL students' writing skills. In WSEAS International Conference Proceedings: Recent Advances in Computer Engineering Series (No. 7). Sliema: Malta.

Zheng, M. H. (2008). Games in the primary English teaching (Unpublished Master's thesis, Nanjing, Normal University, Nanjing Province, China).

Zeng, S. W. (2005). The study of foreign language anxiety and English language strategies in the elementary school (Unpublished Master's thesis, National Taichung University, Taichung, Taiwan). 